\title{
WATER AND ELECTROLYTE BALANCE OF THE DESERT IGUANA, DIPSOSAURUS DORSALIS, IN ITS NATURAL HABI'TAT*
}

\author{
JOHN E. MINNICH† \\ Department of Zoology, University of Michigan, Ann Arbor, Michigan 48104
}

(Received 14 February 1970)

\begin{abstract}
Desert iguanas, Dipsosaurus dorsalis, collected at different times of the year in the Coachella Valley, California, showed no signs of dehydration or accumulation of electrolytes.

2. Variations in body water content and in the distribution of body fluids were related to variations in the amount of fat in the animal.

3. Electrolyte concentrations did not vary in the plasma or intracellular fluid. Variations in urinary electrolytes were correlated with variations in dietary electrolytes.

4. Significant quantities of cations were excreted in the urine as precipitated urate salts. The low solubility of these salts permits their excretion with a small loss of water.
\end{abstract}

\section{INTRODUCTION}

DESERT reptiles face challenging physiological problems of water and electrolyte balance. The desert iguana, Dipsosaurus dorsalis, obtains most of its water from plants which contain electrolyte concentrations that are much higher than those of its body fluids (Minnich \& Shoemaker, 1970). This problem is compounded by the inevitable loss of ion-free water through evaporation. Thus, if desert lizards are to maintain constant internal ion concentrations, they must excrete salts with a small loss of water. The kidney of reptiles, however, is not capable of producing a urine which is hyperosmotic to its body fluids (Smith, 1953). Several species of lizards are capable of excreting high concentrations of electolytes through a salt gland (Schmidt-Nielsen et al., 1963; Templeton, 1964, 1966, 1967; Norris \& Dawson, 1964; Dunson, 1969), but the ability of this gland to handle salt loads incurred in nature has not been characterized. Templeton (1966) found that desert iguanas administered salt loads $(1 \mathrm{ml}$ of $1 \mathrm{M} \mathrm{NaCl}$ or $\mathrm{KCl} / 100 \mathrm{~g}$ body wt. every 6 days) were capable of excreting extrarenally 40 per cent of all injected potassium and 20

* Supported by NSF Grant GB-2447, the Philip L. Boyd Desert Research Center, a Summer Fellowship and Cooperative Graduate Fellowships from NSF, and a Predoctoral Fellowship from NIH. Portions of this paper are contained in the author's Ph.D. thesis at the University of Michigan (1968).

$\dagger$ Present address: Zoology Department, University of Wisconsin-Milwaukee, Milwaukee, Wisconsin 53201. 
per cent of all injected sodium. The salt loads administered these animals, however, were less than those normally encountered in nature (Minnich \& Shoemaker, 1970). Thus desert iguanas must be either accumulating electrolytes during unfavorable times of the year or excreting electolytes with a small loss of water through some additional route besides the salt gland.

This study was undertaken to determine if the desert iguana is capable of regulating its body water and electrolytes at constant levels throughout the year. The study consisted of a seasonal survey of the physiological condition of lizards in the field together with measurements of the rates of loss of water and electrolytes via the kidney, feces and salt gland.

\section{MATERIALS AND METHODS}

\section{Seasonal survey}

The studies presented in this paper were carried out on populations of the desert iguana in the Coachella Valley, Riverside County, California. Lizards were collected in Palm Desert in spring (May 1966), late summer (August 1966) and winter (January 1967). In January 1967 the lizards were in hibernation. The study site had a sparse cover of plants characteristic of low-altitude deserts (creosote bush scrub) and the margins of the site contained irrigated exotic plants. Because of the possibility that desert iguanas may consume irrigation water and exotic plants (see Minnich \& Shoemaker, 1970), lizards were also collected at a nearby site which contained no irrigated exotic plants (Thousand Palms). At the time the lizards were collected at this site (July 1967), the area had not received a measurable rainfall in 6 months and the vegetation was very dry.

Several indexes were used to assess the physiological condition of lizards immediately after capture: content and distribution of body water, and electrolyte concentrations in plasma, tissues and urine. Plasma and total extracellular fluid volumes were measured simultaneously, using Evans Blue (T-1824) and thiocyanate (see Shoemaker, 1964). Lizards were injected in the heart with 0.15 or $0.25 \mathrm{ml}$ of a freshly prepared mixture containing equal volumes of $3 \% \mathrm{w} / \mathrm{v}$ Evans Blue and $10 \% \mathrm{w} / \mathrm{v}$ sodium thiocyanate. Injection was accomplished by using a three-way syringe stopcock fitted with a No. 26 needle, a heparinized, empty syringe used for withdrawal of a plasma blank, and a second syringe containing the dye mixture and fitted with a stop to insure reproducible deliveries. The dye mixture was allowed to equilibrate in the animal for a period of $30 \mathrm{~min}$. Three or four additional blood samples of $0.10 \mathrm{ml}$ each were then obtained by heart puncture at $15-30$-min intervals. They were centrifuged at approximately $500 \mathrm{~g}$ for $10 \mathrm{~min}$ and the hematocrit measured. The cells were discarded and the plasma samples were stored frozen in polyethylene ultramicrocentrifuge tubes until analyzed. Storage of samples in this manner for long periods did not affect their optical density. Concentrations of Evans Blue and thiocyanate were determined spectrophotometrically with the methods used by Shoemaker (1964). Optical densities were extrapolated to zero time to estimate the optical density at the time of injection. Standards were prepared by diluting the injection stocks with water to known volumes. Fluid volumes were calculated from the equation, volume $=K / O . D$., where O.D. is the estimated optical density at the time of injection and $K$ a constant determined from the standards.

Urine samples were collected by inserting a glass capillary $(2 \times 100 \mathrm{~mm})$ into the cloaca just below the ureters for 5-60 min. Since the urine flowed directly from the ureters into the cannula, it was probably not modified by the cloaca (see Roberts \& Schmidt-Nielsen, 1966). Room temperature varied between 25 and $35^{\circ} \mathrm{C}$ during the collection period. Samples showing evidence of fecal contamination were discarded. The $\mathrm{pH}$ of some fresh urine samples was measured on a Beckman zeromatic $\mathrm{pH}$ meter. As in the case of plasma 
samples, urine used for electrolyte measurements was stored frozen in ultramicrocentrifuge tubes until analyzed. The plasma blank and urine samples were diluted 1/500 for measurement of electrolytes. Sodium and potassium concentrations were measured using a Coleman model 21 flame photometer and chloride determinations were performed on an AmincoCotlove chloride titrator.

After collection of plasma and urine samples, animals were killed by double pith, and the liver and approximately $0.5 \mathrm{~g}$ of the muscle from the right thigh were removed for determination of water and electrolyte content. The stomach and cloacal contents and abdominal fat bodies were removed, weighed and the remaining carcass, together with the muscle and liver samples, was dried to constant weight at $105^{\circ} \mathrm{C}$. Total body water was calculated as a percentage of body weight, omitting the contents of the stomach and cloaca, including the fat bodies and correcting for the removed muscle and liver samples. Intracellular fluid volume was calculated from the difference between total body water and extracellular fluid volume. Liver and muscle samples were prepared for electrolyte determinations by soaking $0.1 \mathrm{~g}$ of dried sample in $50 \mathrm{ml}$ of distilled water for 2-7 days.

\section{Excretion}

The desert iguana, like several other reptiles, excretes uric acid as its principal endproduct of nitrogen metabolism. When discharged from the cloaca the urine consists of a semi-solid pellet of uric acid containing very little fluid and, as will be pointed out later, a high content of potassium. Strictly speaking, this pellet does not consist mostly of uric acid, but rather of potassium urate. Therefore, the solid part of the urine will be referred to as "urate" and the fluid part as "urine".

Water and electrolyte content was measured on fecal and urate pellets collected from eight freshly captured desert iguanas. Each lizard was placed for 3 days in an aquarium containing mineral oil beneath a screen which supported the lizard, but allowed passage of the pellets into the oil. Excrement was removed from the cage, cleansed carefully of oil and sun-dried to constant weight. No difference was observed in the water content of pellets treated in this manner and that of fresh pellets not placed in oil. Since these animals were not fed during the collection period they produced fewer pellets than under natural conditions. Therefore, an indirect method was used to estimate natural excretory rates. Rate of defecation of field populations was calculated by multiplying the amount of food eaten/day (Minnich and Shoemaker, 1970) by the dry mass ratio of feces produced/food consumed. The latter figure was determined by Wong \& Shoemaker (personal communication) on desert iguanas maintained on natural dietary items. Output of urate in nature was estimated by multiplying the calculated rate of defecation by the dry mass ratio of urate excreted feces produced. This ratio was determined on the excrement of the eight desert iguanas mentioned above.

Fecal samples were prepared for measurement of electrolytes by soaking approximately $0.1 \mathrm{~g}$ of dried sample in $50 \mathrm{ml}$ of distilled water for 2-7 days. Preparation of urate samples was more involved. Initial soaking of samples in distilled water for 1 week failed to leach out all ions. During this period, the $\mathrm{pH}$ of the solution increased from 5 to 7 or 8 . This suggested that the cations were originally bound to the urate as a urate salt and that a cationhydrogen ion exchange occurred during soaking. Since the solubility of uric acid is less than that of urate salts (Mathews, 1939), a small amount of acetic acid (sufficient to lower the $\mathrm{pH}$ to 5) was added to foster a further cation-hydrogen ion exchange. The samples were then homogenized and diluted with distilled water to a final volume of $100 \mathrm{ml}$ for every $0.01 \mathrm{~g}$ dry wt. of sample. Sodium, potassium and chloride concentrations were measured on all samples, and concentrations calculated in m-equiv/kg dry wt. Concentrations did not change when the solutions were allowed to stand for several weeks. Measurement of electrolyte content with this technique gave results similar to those obtained from urate pellets digested with concentrated nitric acid (Minnich, 1969). 
At the time this study was conducted, difficulty was encountered in measuring excretory rates of the salt gland in the field. Attempts were made to place a "mask" made of Parafilm and masking tape (see Templeton, 1966) on the snout of freshly captured lizards, which were then released. Invariably, the lizard removed the mask before recapture. As an alternative, salt was collected from eight freshly captured lizards maintained for $24 \mathrm{hr}$ in an outdoor cage. A similar "mask" for collecting salt was placed on the snout of these animals, except that the mask was held in place by a piece of tape strapped around the lower jaw. Since the lizards were fasting during the collection period, excretory rates from the salt gland were probably lower than under natural conditions. The salt on the mask and on the snout of the lizard was carefully removed into a clean beaker with a teasing needle that had been rinsed in distilled water and air-dried. Each sample was prepared for electrolyte determinations by dissolving it in $10-40 \mathrm{ml}$ of distilled water.

\section{Statistical tests}

The "Student" two-sample $t$ test (Steel $\&$ Torrie, 1960) was used for determination of any difference between means. In cases where variances were not homogeneous, the modified $t^{\prime}$ test of Cochran \& Cox (1957) was employed. In all cases the level of significance used was $P=0.05$. Variation of a population around a mean is expressed in this paper as standard errors.

\section{RESULTS}

\section{Seasonal survey}

Body fluid distribution. 'Total body water in desert iguanas during summer approximated three-fourths of the body weight $(74.7 \pm 0.38 \mathrm{ml} / 100 \mathrm{~g}$ in Palm Desert and $73.8 \pm 0.38 \mathrm{ml} / 100 \mathrm{~g}$ in Thousand Palms) and was partitioned into about $45 \mathrm{ml} / 100 \mathrm{~g}$ intracellular fluid and $30 \mathrm{ml} / 100 \mathrm{~g}$ extracellular fluid. Approximately $5 \mathrm{ml} / 100 \mathrm{~g}$ body wt. of the extracellular space was blood plasma volume. Total body water of spring lizards $(72.4 \pm 0.38 \mathrm{ml} / 100 \mathrm{~g}$ in males and $70.9 \pm 0.56 \mathrm{ml} / 100 \mathrm{~g}$ in females) was significantly lower than that of summer lizards, both in Palm Desert and Thousand Palms $(P<0.02$ for males and $P<0.001$ for females) and was probably related to the greater fat content of the former. The abdominal fat bodies of spring females were significantly heavier than those of summer females $(P<0 \cdot 001)$. A similar trend was apparent in male lizards, although the difference was not significant. The difference in the weight of these fat bodies was not sufficient to account for the total difference in body water between spring and summer lizards, but it should be indicative of the differences in the total fat of the animals. In addition, spring females were heavily laden with eggs. The low intracellular fluid volume of spring lizards $(41.3 \pm 0.77 \mathrm{ml} / 100 \mathrm{~g}, P<0.01$ when compared to summer lizards) was presumably also related to high fat content. Plasma volumes, total extracellular fluid volumes and water contents of muscle $(79 \mathrm{ml} / 100$ g) and liver $(75 \mathrm{ml} / 100 \mathrm{~g})$ did not differ among any of the groups.

Winter lizards were found to have an unusually high total body water $(78.4 \pm$ $0.46 \mathrm{ml} / 100 \mathrm{~g})$, higher than any of the other groups $(P<0.001)$. This is probably an artefact of the small size of the animals obtained in winter. All winter lizards were small juveniles, less than $60 \mathrm{~mm}$ in snout-vent length. Juvenile lizards have a higher content of total body water than adult lizards (Khalil \& Abdel-Messeih, 1954). 
Electrolyte concentrations. A review of the electrolyte composition of the diet of each population (Minnich \& Shoemaker, 1970) will facilitate our understanding of the electrolyte concentration in their body fluids. Potassium concentrations in the food were uniformly high, while those of sodium and chloride were low and intermediate, respectively. The electrolyte concentrations in the diet of lizards from Palm Desert did not shift markedly with season. The only significant change was the lower sodium concentrations during the summer. At Thousand Palms during the summer, the food had higher sodium and potassium concentrations and lower chloride concentrations than at Palm Desert.

Electrolyte concentrations in the tissues and plasma were similar in all populations of desert iguanas (Table 1). Even though the mean plasma sodium and chloride levels of winter lizards were low, they were not significantly different from the others. Only the low plasma chloride concentration of lizards from Thousand Palms was significantly different from that of the other active populations $(P<0.05)$. This was correlated with the low dietary chloride of that population.

Urinary potassium concentrations were uniformly high while concentrations of other urinary electrolytes varied with the diet (Table 1). Sodium concentrations in the urine of summer lizards in Palm Desert were significantly lower than those of other populations $(P<0 \cdot 05)$ and reflected the low sodium concentrations in their diet. There was a progressive decrease in urinary chloride levels from winter to summer. The concentrations in winter lizards were significantly higher than those of the other groups $(P<0 \cdot 001)$ and those of spring lizards were significantly higher than either of the summer populations $(\mathrm{P}<0.05$ and $\mathrm{P}<0.01$, when compared to lizards from Palm Desert and Thousand Palms, respectively). The low urinary chloride of lizards from Thousand Palms was correlated with the low dietary chloride but that of summer animals from Palm Desert was probably related to the low urinary sodium concentrations.

The $\mathrm{pH}$ of ureteral urine of six desert iguanas in the field varied from $7 \cdot 15$ to $7 \cdot 28$.

Although osmotic pressures of intracellular fluid, plasma and urine were not measured, the sum of the cations $(\mathrm{Na}+\mathrm{K})$ should give an indication of their relative osmolality. The cationic concentrations were similar in tissue fluid (muscle, liver) and plasma in all active populations of desert iguanas (Table 1). Only those of winter lizards were significantly lower than the others $(P<0 \cdot 05)$. The cationic concentrations in the urine suggested that the urine osmolality was uniformly low in all populations, except possibly in winter lizards. Certain other uricotelic reptiles also produce urine of consistently low osmolality (Roberts \& Schmidt-Nielsen, 1966; Dantzler \& Schmidt-Nielsen, 1966; Schmidt-Nielsen \& Skadhauge, 1967).

To summarize, desert iguanas sampled at different times of the year showed no evidence of dehydration or accumulation of elecrolytes. Variations in body water content and in the distribution of body fluids were probably related to variations in the amount of fat in the animal. Electrolyte concentrations did not vary much in the body fluids, except the urine, where they reflected variations in dietary electrolytes. 
John E. Minnich

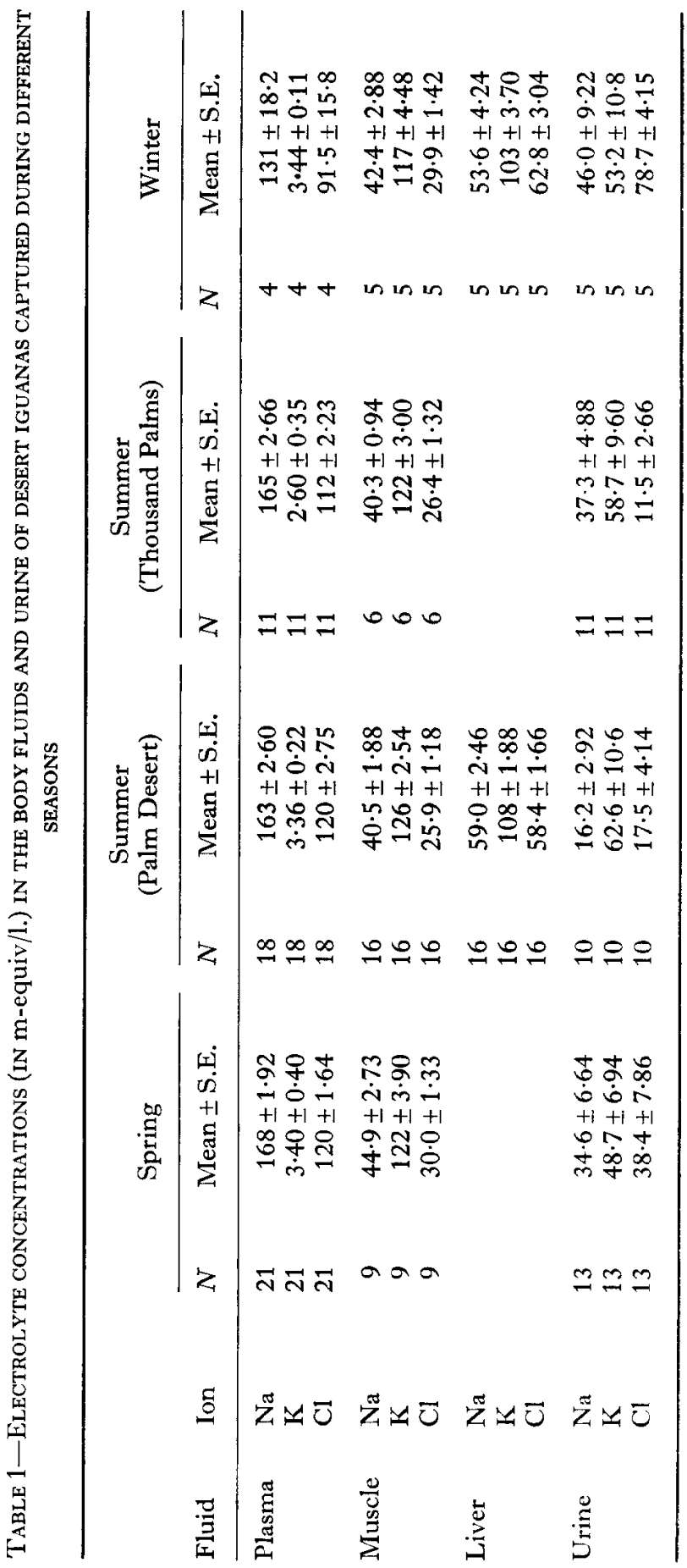




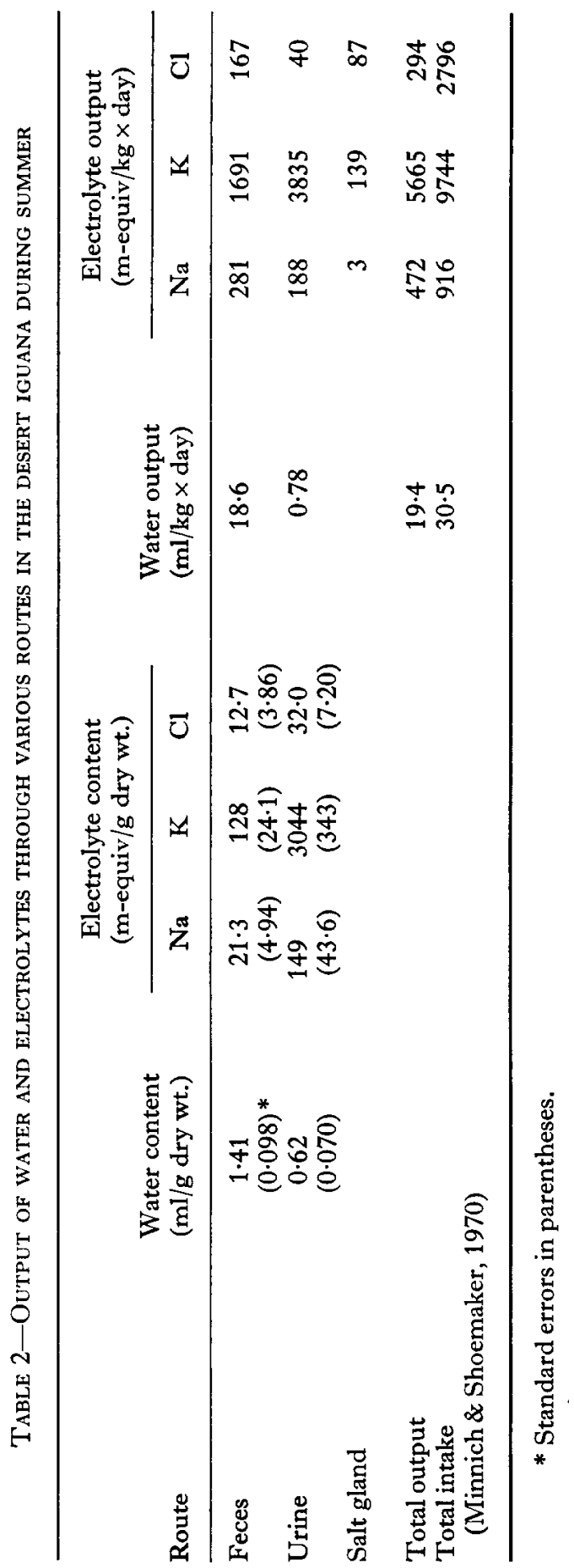




\section{Excretion}

The electrolyte composition of the excrement, like that of the ureteral urine, was strongly correlated with the dietary electrolytes (Table 2). The feces and urate contained about six- to twentyfold more potassium than sodium and the salt incrustations from the nasal gland contained almost no sodium. The chloride content, however, differed among the various excreta. While the chloride levels in the feces and urate were very low, those in the salt incrustations were quite high, balancing about two-thirds of the sodium and potassium. The remaining anion was presumably bicarbonate (see Norris \& Dawson, 1964). The remaining anions in the feces were not determined, but those in the urate pellets were probably urate (Minnich, 1968).

While the amount of cations/unit of water in the feces was lower than in the food, those in the urate were much higher (see Table 2). Milliequivalents of sodium plus potassium/l. water were $0 \cdot 4,0 \cdot 1$ and $5 \cdot 2$ for food, feces and urate, respectively. 'The quantities of potassium/unit of water in the urate were five times higher than in the nasal fluid of the false iguana (Ctenosaura pectinata) stimulated with injection of $6.5 \mathrm{ml}$ of $1 \mathrm{~N} \mathrm{KCl} / 100 \mathrm{~g}$ body wt. (Templeton, 1964). Thus excretion of urate salts appears to be a very efficient means of excreting cations with a small loss of water.

Excretory rates of water and electrolytes from lizards in the field are presented in Table 2. About two-thirds of the excreted potassium and 40 per cent of the excreted sodium were lost through urate excretion, and 60 per cent of the excreted sodium and most of the chloride were lost in the feces. The salt gland appeared to contribute very little to electrolyte excretion. Total output of sodium and potassium through all routes accounted for about one-half of the intake estimated by Minnich \& Shoemaker (1970) and chloride output accounted for about one-tenth of the estimated intake. About two-thirds of the water intake was lost through defecation, with only one-fourtieth lost through urate excretion (Table 2).

\section{DISCUSSION}

The desert iguana can maintain normal electrolyte balance at all times of the year. It does not show any evidence of dehydration or accumulation of electrolytes, even after a drought of 6 months. Variations occur only in content of body water and in concentrations of the component urinary electrolytes. The former is the result of variability in fat content, the latter is related to variations in the electrolyte composition of the diet. This pattern of water and electrolyte balance is very different from the seasonal variations found in the Australian lizard, Amphibolurus ornatus. This animal accumulates sodium during the dry season (Bradshaw \& Shoemaker, 1967). The excess sodium is stored in the extracellular fluid, which results in its expansion at the expense of the intracellular fluid. Amphibolurus is insectivorous, feeding almost exclusively on ants of the genus Iridomyrmex. These ants contain high sodium concentrations, approximating levels of potassium found in the food of desert iguanas. During summer rains, Amphibolurus drinks enough 
water to excrete the excess electrolytes without incurring a water deficit (Bradshaw $\&$ Shoemaker, 1967). The desert iguana also drinks rain water (Minnich \& Shoemaker, 1970), but does not rely on it for excretion of electrolytes. Unlike desert iguanas, Amphibolurus is apparently not capable of excreting excess sodium with a small loss of water.

In winter the osmotic concentrations of the body fluids of desert iguanas apparently fall to values below those of active lizards. Similar results have been reported in Varanus griseus (Haggag et al., 1965). During hibernation sodium and chloride decrease, and potassium, calcium and magnesium increase in the plasma of this monitor lizard. Although the results are extremely variable, the plasma of desert iguanas shows the same trends: decreased sodium and chloride and increased potassium. The chloride concentrations in the urine of winter animals are very high. These shifts in electrolyte concentrations are probably the result of reduced metabolic rate. Moberly (1962) found that the metabolic rate of hibernating desert iguanas was reduced, when compared to that of active lizards at the same temperatures. When the metabolism slows, the ability of tissues to maintain ionic gradients is apparently reduced. Potassium leaks from the cells into the extracellular fluid, sodium does the reverse. Electrolyte concentrations increase in the usually dilute urine. Several lizards, especially thermophilic species, produce urine containing high electrolyte concentrations at low temperatures (Shoemaker et al., 1966, 1967). The reduced osmolality of the body fluids may also be related to reduced metabolic rate.

Desert iguanas do not show signs of electrolyte accumulation during summer because they are capable of excreting electrolytes with a small loss of water. In addition to possessing a salt gland, desert iguanas excrete urate pellets containing small quantities of water, a moderate content of sodium and a very high content of potassium. These electrolytes are apparently in the form of relatively insoluble urate salts. Uric acid is a purine derivative which exists in two forms, a lactam or "keto" form and a lactim or "enol" form (Mitchell, 1946). Enolization at two positions appears to account for the formation of two series of urate salts. The $\mathrm{p} K_{A}$ values for these salts are approximately 5.7 and 9.8. The solubility of uric acid and its two series of salts increases with increasing $\mathrm{pH}$ (Mathews, 1939). The disodium and dipotassium urate salts are somewhat soluble in water, the equivalent acid (mono-) urates are less soluble. The solubility of monosodium urate is $6 \cdot 76$ $\mathrm{m}$-moles/1., that of monopotassium urate is $12.06 \mathrm{~m}$-moles/1. (Dantzler \& SchmidtNielsen, 1966). Uric acid has a solubility of 0.384 m-moles/l. (Dantzler, 1968).

The $\mathrm{pH}$ of ureteral urine of desert iguanas $(7 \cdot 15-7 \cdot 28)$ suggests that urate exists predominantly as a mono-urate salt. The large quantities of potassium present suggest that the pellets are primarily monopotassium urate. Lesser amounts of monosodium urate must also be present. The way in which these salts are formed is unknown, but comparison of the ureteral and discharged urine may give some clues. The ureteral urine of desert iguanas is always a dilute fluid, containing moderate quantities of potassium, a small amount of sodium and chloride and very little precipitated uric acid. Because of its low solubility product, very 
little uric acid must be in solution. However, moderate quantities of uric acid may be present in colloidal form. This has been demonstrated in the urine of pigeons (McNabb \& Poulson, 1968). The discharged urine of desert iguanas, however, consists of a precipitated pellet of insoluble potassium urate containing very little water. Apparently the urine is modified in some manner by the cloaca. Preliminary work in my laboratory suggests that sodium chloride and water are reabsorbed in the cloaca, causing precipitation of potassium urate. The cloaca of snakes appears to function in this manner (Junqueira et al., 1966). In addition, if colloidal urate is present, the colloid may be dispersed in the cloaca.

The kidney of the desert iguana always produces a dilute urine, regardless of the state of hydration. In this way it resembles the kidneys of geckos (Roberts \& Schmidt-Nielsen, 1966), desert tortoises (Dantzler \& Schmidt-Nielsen, 1966) and crocodiles (Schmidt-Nielsen \& Skadhauge, 1967). All of these species are predominantly uricotelic. In these species there is very little variation in the distal tubular permeability to water. Regulation of water excretion occurs principally through variations in glomerular filtration rate and water reabsorption in the cloaca and bladder (Schmidt-Nielsen \& Skadhauge, 1967). These may be characteristics that permit uricotelism because they minimize the tendency of uric acid to clog the kidney tubules and ureters.

Excretion of potassium and sodium as precipitated urate salts permits the elimination of large quantities of these ions with a small loss of water. The only other mechanism by which reptiles are capable of excreting salts with a small loss of water is the salt gland. Schmidt-Nielsen et al. (1963) suggest that the latter is the major, if not exclusive, mechanism for the excretion of salts in reptiles and birds. They reasoned that uric acid is precipitated in the cloaca by the removal of water and that active uptake of salts by the cloaca causes water removal. Such a mechanism leaves the reptile or bird with the problem of excreting the salt that is moved across the cloaca into the blood. This function is presumably performed by the salt gland. Cloacal reabsorption of salt, however, does not mean that all salt is reabsorbed. The studies presented in this paper suggest that the desert iguana excretes significant quantities of potassium and sodium via the cloaca as precipitated urate salts. Similar results are reported by Dunson (1969) for the Galapagos marine and land iguanas. Excretion of salts in this form would permit such desert lizards as Coleonyx, which has no salt gland (Minnich, unpublished), to eliminate salts with a small loss of water.

In this study the salt gland of the desert iguana contributed very little to electrolyte excretion, when compared to the kidney (see Table 2). These estimates of salt gland excretion were probably lower than in nature because they were based on the amount of salt excreted by fasting lizards in $24 \mathrm{hr}$. Templeton (1969) states that dehydrated desert iguanas recently captured in the field and maintained on lettuce excreted more potassium and sodium through the nasal gland than through the kidney. Since desert iguanas did not accumulate electrolytes during summer (Table 1), the salt gland probably excreted the ingested electrolytes that were not lost in the feces and urine. If the salt gland were to excrete these electrolytes, it 
would produce $0 \cdot 4,4 \cdot 2$ and $2 \cdot 6$ m-equiv $/(\mathrm{kg} \times$ day) of $\mathrm{Na}, \mathrm{K}$ and $\mathrm{Cl}$, respectively (see Table 2). Secretory rates of this magnitude are near the maximal physiological capability of desert iguanas (Templeton, 1966; Shoemaker, personal communication). In marine birds (Schmidt-Nielsen, 1960), the green sea turtle (Holmes \& McBean, 1964), sea snakes (Dunson \& Taub, 1967; Dunson, 1968) and the Galapagos marine and land iguanas (Dunson, 1969), electrolyte excretion by the salt gland matches or exceeds that of the kidney. The relative importance of the salt gland in the electrolyte balance of the desert iguana is uncertain, but it is probably more important than the data in Table 2 suggest.

With the available information, a complete budget of water and electrolytes can be estimated for the desert iguana. The total intake of water was determined by Minnich \& Shoemaker (1970), using tritiated water, to be $30 \mathrm{ml} /(\mathrm{kg} \times$ day), $3.6 \mathrm{ml} /(\mathrm{kg} \times$ day $)$ of which was produced through metabolism. Total intake of sodium, potassium and chloride was estimated at $0.9,9.6$ and $2.7 \mathrm{~m}$-equiv $/(\mathrm{kg} \times$ day), respectively (Minnich \& Shoemaker, 1970). Approximately two-thirds of the water intake was estimated in this study to be lost in the feces and an additional $0.78 \mathrm{ml} /(\mathrm{kg} \times$ day) in the urine (Table 2). Evaporative water loss was estimated by Minnich (1970) to be $8.6 \mathrm{ml} /(\mathrm{kg} \times$ day). This would leave approximately 2.5 $\mathrm{ml} /(\mathrm{kg} \times$ day $)$ to be lost through the salt gland. If the salt gland excretes the electrolytes not lost through the urine or feces, it would produce fluid containing concentrations of $180 \mathrm{~m}$-equiv. $\mathrm{Na} / \mathrm{l}, 1700 \mathrm{~m}$-equiv. $\mathrm{K} / \mathrm{l}$. and $1000 \mathrm{~m}$-equiv. $\mathrm{Cl} / \mathrm{l}$. Such concentrations are within the known range of terrestrial lizards (SchmidtNielsen et al., 1963; Templeton, 1964). Most potassium apparently is excreted in the urine as urate salts, but the salt gland probably excretes most of the ingested chloride.

The chief characteristics of the water budget of the desert iguana are (1) the small proportion of water produced through metabolism and (2) the large proportion of water lost through defecation. These features are due to the desert iguana's low level of metabolism and to its relatively inefficient digestion of plant food. Desert iguanas maintained on Coldenia plicata and Dalea emoryi, two important dietary items (Minnich \& Shoemaker, 1970), have digestive efficiencies of 30 and 50 per cent, respectively. The insectivorous lizard Uma scoparia, on the other hand, has a digestive efficiency of 94 per cent when maintained on mealworms (Wong \& Shoemaker, personal communication). Metabolism of lizards is about one-seventh that of a mammal of comparable size at the same body temperature (Schmidt-Nielsen \& Dawson, 1964). The consequences of low metabolic rate are reduced evaporative water losses, reduced production of oxidative water and generally a lower rate of water turnover. Desert iguanas compensate for inefficient digestion by ingesting large quantities of food. The consequence of this is large fecal loss of water.

Acknowledgements - I wish to thank Dr. William R. Dawson for his invaluable guidance during this study. I am also grateful to Drs. W. A. Dunson, V. H. Shoemaker and J. G. Stanley for critically evaluating the manuscript and to Dr. R. Ruibal and Mr. Lloyd Tevis for making possible the use of the facilities at the Philip L. Boyd Desert Research Laboratory. 


\section{REFERENCES}

Bradshaw S. D. \& Shoemaker V. H. (1967) Aspects of water and electrolyte changes in a field population of Amphibolurus lizards. Comp. Biochem. Physiol. 20, 855-865.

Cochran W. G. \& Cox G. M. (1957) Experimental Designs, 2nd edn. John Wiley, New York.

DANTzLER W. H. (1968) Effect of metabolic alkalosis and acidosis on tubular urate secretion in water snakes. Am. F. Physiol. 215, 747-751.

Dantzler W. H. \& Schmidt-Nielsen B. (1966) Excretion in freshwater turtle (Pseudemys scripta) and desert tortoise (Gopherus agassizii). Am. F. Physiol. 210, 198-210.

Dunson W. A. (1968) Salt gland secretion in the pelagic sea snake Pelamis. Am. F. Physiol. 215, 1512-1517.

Dunson W. A. (1969) Electrolyte excretion by the salt gland of the Galapagos marine iguana. Am.F. Physiol. 216, 995-1002.

Dunson W. A. \& TAub A. M. (1967) Extrarenal salt excretion in sea snakes (Laticauda). Am. J. Physiol. 213, 975-982.

Haggag G., Khamis A. \& Kalil F. (1965) Hibernation in reptiles. I-Changes in blood electrolytes. Comp. Biochem. Physiol. 16, 457-465.

Holmes W. N. \& McBean R. L. (1964) Some aspects of electrolyte excretion in the green turtle, Chelonia mydas mydas. F. exp. Biol. 41, 81-90.

Junqueira L. C. U., Malnic G. \& Monge C. (1966) Resorptive function of the ophidian cloaca and large intestine. Physiol. Zoöl. 39, 151-159.

Khalil F. \& ABDEL-Messeih G. (1954) Water content of tissues of some desert reptiles and mammals. F. exp. Zool. 125, 407-414.

Mathews A. P. (1939) Physiological Chemistry. Williams \& Wilkins, Baltimore.

McNabi F. M. A. \& Poulson T. L. (1968) Uric acid excretion in pigeons. Am. Zoologist $8,777$.

Minnich J. E. (1968) Maintenance of water and electrolyte balance by the desert iguana, Dipsosaurus dorsalis. Am. Zoologist 8, 782.

Minnich J. E. (1969) Excretion of urate salts by reptiles. Am. Zoologist 9, 1094.

MinNich J. E. (1970) Evaporative water loss from the desert iguana, Dipsosaurus dorsalis. Copeia. (In press.)

Minnich J. E. \& Shoemaker V. H. (1970) Diet, behavior and water turnover in the desert iguana, Dipsosaurus dorsalis. Am. Midl. Nat. (In press.)

Mitchell P. H. (1946) A Textbook of Biochemistry. McGraw-Hill, New York.

Moberly W. R. (1962) Hibernation in the desert iguana, Dipsosaurus dorsalis. Physiol. Zoöl. 36, $152-160$.

Norris K. S. \& Dawson W. R. (1964) Observations on the water economy and electrolyte excretion of chuckwallas (Lacertilia, Sauromalus). Copeia 1964, 638-646.

Roberts J. S. \& Schmidt-Nielsen B. (1966) Renal ultrastructure and excretion of salt and water by three terrestrial lizards. Am. F. Physiol. 211, 476-486.

Schmid'-Nielsen K. (1960) The salt secreting gland of marine birds. Circulation 21, 955-967.

Schmidt-Nielsen K., Borut A., Lee P. \& Crawford E. (1963) Nasal salt excretion and the possible function of the cloaca in water conservation. Science 142, 1300-1301.

Schmidt-Ninlsen K. \& Dawson W. R. (1964) Terrestrial animals in dry heat: desert reptiles. In Handbook of Physiology, Section 4, Adaptation to the Environment (Edited by Dilu B. D.), pp. 467-480. American Physiological Society, Washington, D.C.

Schmidt-Nielsen B. \& Skadhauge E. (1967) Function of the excretory system of the crocodile (Crocodylus acutus). Am. F. Physiol. 212, 973-980.

Shoemaker V. H. (1964) Physiological effects of water deprivation in a toad, Bufo marinus. Ph.D. thesis, University of Michigan, Ann Arbor. 
Shoemaker V. H., Licht P. \& Dawson W. R. (1966) Effects of temperature on kidney function in the lizard Tiliqua rugosa. Physiol. Zool. 39, 244-252.

Shoemaker V. H., Licht P. \& Dawson W. R. (1967) Thermal dependence of water and electrolyte excretion in two species of lizards. Comp. Biochem. Physiol. 23, 255-262.

Smith H. W. (1953) From Fish to Philosopher. Little \& Brown, Boston.

Steel R. G. D. \& Torrie J. H. (1960) Principles and Procedures of Statistics. McGraw-Hill, New York.

Templeton J. R. (1964) Nasal salt excretion in terrestrial lizards. Comp. Biochem. Physiol. 11, 223-229.

Templeton J. R. (1966) Responses of the lizard nasal gland to chronic hypersalemia. Comp. Biochem. Physiol. 18, 563-572.

Templeton J. R. (1967) Nasal salt gland excretion and adjustment to sodium loading in the lizard, Ctenosaura pectinata. Copeia 1967, 136-140.

Templeton J. R., Randall E., Mugaas J. \& Murrish D. (1969) Nasal and renal salt excretion in the desert iguana, Dipsosaurus dorsalis. Am. Zoologist 9, 587.

Key Word Index-Desert; lizard; electrolytes; water balance; body fluid volumes; hibernation; season; excretion; salt gland; kidney; cloaca; urate salts. 